\title{
PENGELOLAAN WAKAF ALKHAIRAAT PALU SULAWESI TENGAH
}

\author{
Ahmadan B. Lamuri \\ Universitas Alkhairaat, Jl. Diponegoro Palu 94221 \\ E-mail: amalanlan@yahoo.co.id
}

\begin{abstract}
Abstrak. Alkhairaat adalah salah satu lembaga pendidikan yang memiliki lembaga wakaf. Tetapi pengelolaan wakaf masih bersifat tradisional, kurang memerhatikan aspek kelembagaannya, standarisasi kemampuan pengelolanya, manfaat dan pengembangan harta wakaf. Akibatnya wakaf tidak memiliki daya dorong bagi pengembangan ekonomi, daya tarik kepercayaan publik, daya penentu sistem pengelolaan perekonomian, serta daya saing atau kompetisi kelembagaan baik internal maupun eksternal. Diharapkan perhimpunan Alkhairaat selalu berusaha memperbaiki sistem manajerial pengelolaan wakafnya, dengan memperhatikan esensi yang terkandung dalam wakaf, sekaligus membangun kemandirian lembaga wakafnya agar dapat menerapkan manajemen dengan baik.
\end{abstract}

Abstract. Alkhairaat is one of institutions of education that possesses waqf institution. Nevertheless, the waqf institution is still managed traditionally, the lack of attention to the aspect of the development of the waqf institution, to that of standardization of its managers, to that aspect of the benefits and to that of the development of waqf property. As a result, the waqf institution administered do not possess driving force towards the economic development, the attractiveness of public trust, determinant force of economic management system as well as the competitiveness of the institution, both internally and externally. Based on the facts, it is suggested that the Alkhairaat organization attempt to improve the managerial system of its waqf, paying attention to the essence of the waqf, and to establish the independence of its waqf institution in order to be able to implement good management.

Kata kunci: Alkhairaat, pengelola wakaf (nāzirir), manajemen. 


\section{PENDAHULUAN}

Menengok pada sejarah, wakaf sebenarnya telah dikenal dan dilaksanakan oleh umat Islam sejak agama Islam ini berkembang. Telah diakui menjadi penunjang perkembangan masyarakat Islam, walaupun belum memberikan korelasi yang signifikan bagi pemberdayaan masyarakat. Oleh sebab itu, gerakan "wakaf" harus menjadi garapan utama sebagai instrumen ekonomi agar memberi kontribusi besar bagi kesejahteraan sosial $^{2}$. Di Indonesia, menurut Muhammad Fuad, pengelolaan wakaf masih jauh dari yang diharapkan, baru lembaga ZIS yang mulai terkelola dengan baik yang melibatkan lembaga profesional dan modern. ${ }^{3}$ Ketradisionalan dalam pengelolaan masih tampak, akibatnya-menurut Suhrawardi Lubis-wakaf bukan menjadi produktif tetapi justru memberi beban bagi umat. ${ }^{4}$ Tim CSRC (Center for the Study of Religion and Culture) UIN Syarif Hidayatullah mengungkap bahwa harta wakaf berupa bangunan yang berdiri di atas tanah wakaf mencapai (87\%), tetapi praktek pembiayaannya paling menonjol bersumber dari masyarakat (88\%) dan dari hasil wakaf itu sendiri hanya sekitar $9 \%{ }^{5}$

${ }^{1}$ Lihat: Imam Suhadi, Wakaf untuk Kesejahteraan Umat (Cet. ke-1; Yogyakarta: Dana Bhakti Prima Yasa, 2002), h. 38; Abd. Ghafur Anshari, Hukum dan Praktek Perwakafan di Indonesia (Cet. ke-2; Yogyakarta: Pilar Media, 2006), h. 18

${ }^{2}$ Edwin Nasution mengatakan bahwa wakaf sebagai instrument ekonomi Islam yang sangat potensial dalam meningkatkan kesejahteraan sosial memiliki peran yang sangat besar dalam membantu menyelesaikan masalah sosial ekonomi masyarakat jika dikelola secara profesional dan produktif. Edwin Nasution, (ed.), "Peran Badan Wakaf Indonesia (BWI) dalam Pengembangan Wakaf di Indonesia" dalam Jurnal al-Awqaf, Vol. 1 No. 1, (2008), h. 1

${ }^{3}$ Muhammad Fuad, Membangunkan Raksasa Tidur Problematika Pengelolaan dan Pendayagunaan Wakaf di Indonesia (Cet. ke-1; Jakarta: Piramedia, 2008), h. 2

${ }^{4}$ Suhrawardi K . Lubis, dkk., Wakaf dan Pemberdayaan Umat (Cet. ke-1; Jakarta : Sinar Grafika, 2010), h. 101

${ }^{5}$ Tuti A. Najib, (ed.), Wakaf, Tuhan dan Agenda Kemanusiaan Studi tentang Wakaf dalam Perspektif Keadilan Sosial di Indonesia (Cet. ke-1; Jakarta: CSRC UIN Syarif, 2006), h. 120 
Pengelolaan wakaf banyak dilakukan oleh lembaga pendidikan; termasuk Alkhairaat. Penyebaran wakafnya berada di hampir seluruh daerah kerjanya. Di kota Palu, misalnya, data dari kantor Pengurus Besar Alkhairaat tercatat sebanyak 17 lokasi (Data PB, 1999), tetapi ini belum semua terdata karena baru di Kecamatan Palu Barat, sementara di kecamatan lainnya tidak ada datanya. Di kabupaten Poso, menurut laporan Komisariat Daerahnya (KOMDA, 2010) tanah/lahan wakaf yang berdiri madrasah di atasnya ada 46 lokasi; sementara dilihat dari aspek pendataan kejelasan status tanah yang dinyatakan sebagai wakaf, baru 14 lokasi atau $\pm 30 \%$. Aset wakaf yang sangat strategis lainnya yakni dana abadi. Laporan Ketua Yayasan Alkhairaat di Muktamar Alkhairaat VIII tahun 2002 menyebutkan total penerimaan keuangan dana abadi Rp. 1.953.456.960. ${ }^{6}$ Dilihat tenggang waktu penerimaan sampai pelaksanaan muktamarnya tahun 2014, seyogyanya dana itu telah mengalami peningkatan jumlah yang signifikan, namun realitasnya belum dapat diketahui seberapa besar peningkatan dan pengaruhnya terhadap penerimaan hasil wakaf. Oleh karena itu, sangat jelas bahwa wakaf di Alkhairaat belum dikelola dengan sebaik-baiknya. Muhammad Fuad mengemukakan belum terkelolanya wakaf dengan baik disebabkan oleh rendahnya pemahaman wakif, pengelola, dan masyarakat umum tentang hukum wakaf dan kurang memiliki kapasitas manajemen. ${ }^{7}$

Jika Alkhairaat berkepentingan terhadap wakaf seharusnya ada langkah dan upaya pemetaan masalah berdasarkan skala prioritas melalui inovasi. Dana abadi seyogyanya dikelola dengan menggunakan manajemen investasi; dengan prinsip menanamkan modal yang masih terbatas tetapi akan mendapatkan keuntungan yang banyak; seperti diungkapkan oleh ahli ekonomi

${ }^{6}$ Fadel Muhammad, Sambutan Ketua Yayasan Alkhairaat pada Muktamar Besar VIII, Palu, 2002, h. 9.

${ }^{7}$ Muhammad Fuad, Membangunkan..., h. 4 
"mendapatkan keuntungan yang setinggi-tingginya dengan modal yang serendah-rendahnya".

Kondisi pengelolaan wakaf Alkhairaat antara data dan realitas berbeda, melahirkan masalah yang perlu diselesaikan, yaitu menyangkut kualitas pengelola wakaf dan penerapan manajemen, dengan mengemukakan beberapa masalah: 1) Bagaimana bentuk pengelolaan wakaf Alkhairaat Palu Sulawesi Tengah; 2) Apakah Alkhairaat dalam mengelola wakafnya telah menggunakan teori-teori manajemen; 3) Apa yang menjadi faktor pendukung dan penghambat pengelolaan wakaf Alkhairaat yang sesuai dengan fungsi manajemen.

\section{METODE PENELITIAN}

Penelitian ini berdasarkan sifatnya, merupakan "penelitian kualitatif" yang akan mencoba mengungkap realitas pengelolaan wakaf di Alkhairaat Palu Sulawesi Tengah. Penelitian ini adalah penelitian lapangan dengan menggunakan pendekatan ilmu manajemen dan hukum Islam ${ }^{9}$. Sumber data diperoleh melalui kantor Pengurus Besar Alkhairaat bidang wakaf selaku administrator. Pengumpulan data menggunakan sumber primer

${ }^{8}$ H. Veithzal Rivai, Islamic Financial Management (Cet. ke-1; Bogor: Ghalia Indonesia, 2010), h. 421

${ }^{9}$ Materi wakaf merupakan bagian dari kajian hukum Islam, maka dalam penelitian ini akan menjelaskan masalah-masalah wakaf berdasarkan kaedahkaedah fiqhiyyah. Kajian seperti ini biasa juga disebut pendekatan Teleologis. Teleologis berasal dari bahasa Yunani yaitu teleos yang artinya selesai, atau lengkap. Sedang menurut istilah teleologiy dipahami sebagai teori yang menyatakan bahwa dalam suatu proses terkandung suatu kegiatan yang bertujuan dan bebas serta bukannya hanya kebetulan. Tujuan tersebut sudah direncanakan dan dibimbing menuju sesuatu yang ingin dicapai atau tujuan yang ideal. Lihat: Abd. Muin Salim, Fiqh Siyasah, Konsepsi Kekuasaan Politik dalam Alqur'an (Cet. ke-2; Jakarta: Raja Grafindo Persada, 1995), h. 28; Ali Mudhafir, Kamus Teori dan Aliran dalam Filsafat dan Teologiy (Cet. 1; Yogyakarta: UGM Press, 1996), h. 257 
dan sumber sekunder. Penelitian ini bercorak lapangan, maka data pokoknya dari hasil observasi, dokumen, dan wawancara. ${ }^{10}$

Analisis data dilakukan secara deskriptif yakni mendeskripsikan fenomena, mengklasifikasikan, dan melihat bagaimana konsep yang muncul itu memiliki keterkaitan. Langkah pertama adalah mengembangkan deskripsi yang komprehensif dan teliti dari hasil penelitian; membuat perbandingan yang bermakna antara setiap bagian dari data tentang pengelolaan wakaf yang ada di kantor Pengurus Besar dengan kenyataan yang terjadi di lapangan. Jika antara sistem administrasi dan data aset wakaf di lapangan masih berbeda; maka ada kemungkinan sistem manajemen yang digunakan masih bersifat tradisional dan apa adanya; tetapi jika memiliki kesesuaian, maka kemungkinan sistem pengelolaannya telah menggunakan manajemen yang profesional.

\section{HASIL DAN PEMBAHASAN}

\section{Pengertian dan Jenis Wakaf yang Dikelola Alkhairaat}

\section{Pengertian Wakaf}

Wakaf memiliki padanan kata yang beragam, yakni sebagai al-khair, șadaqah jāriyah, dan sebagai al-aḥbās. Al-khair artinya kebaikan, hubungan dengan wakaf berarti "berbuat baik melalui harta benda". Șadaqah jāriyah yakni sedekah yang pahalanya mengalir terus walaupun pemberinya telah meninggal dunia. Al-

${ }^{10}$ Wakaf termasuk materi kajian hukum Islam, maka pengambilan data primernya adalah bahan-bahan yang erat dengan peraturan perundangundangan dan juga kaedah-kaedah fiqhiyah. Ini hanya akan diperoleh melalui pustaka atau dokumen-dokumen; sedangkan data lapangan menjadi data sekunder yang dalam ilmu sosial menjadi data primer. Zainuddin Ali, Metode Penelitian Hukum (Cet. ke-2; Jakarta: Sinar Grafika, 2010), h. 47 
habs artinya "mencegah atau diam". ${ }^{11}$ Wakaf berarti menahan harta dan memberikan manfaatnya di jalan Allah. ${ }^{12}$

Di kalangan mazhab Syafi'i, wakaf dipahami menahan harta yang dapat diambil manfaatnya dengan tetap utuhnya barang, dan barang tersebut hilang kepemilikannya dari wakif, serta dimanfaatkan pada sesuatu yang dibolehkan; atau menahan yang bisa diambil manfaatnya dengan menjaga bentuk aslinya untuk disalurkan kepada jalan yang dibolehkan. ${ }^{13}$

Jumhur ulama berpendapat bahwa wakaf yaitu menahan tindakan hukum orang yang berwakaf terhadap hartanya yang telah diwakafkan dengan tujuan untuk dimanfaatkan bagi kepentingan umum dan kebaikan dalam rangka mendekatkan diri pada Allah swt, sedangkan materinya tetap utuh. Lebih lanjut jumhur berpendapat bahwa harta yang sudah diwakafkan tidak lagi menjadi milik wakif dan akadnya bersifat mengikat dan status harta telah berubah menjadi milik Allah swt. yang dipergunakan

\footnotetext{
${ }^{11}$ Ibrāhīm Maḥmūd 'Abd al-Bāqī, Daur al-Waqf fī Tanmiyat al-Mujtama' al-Madanī, Namūzuj al-Amānah al-'̄mmmah li al-Awqäf bi Daulah al-Kuwait, Disertasi tidak diterbitkan (Kuwait, 2006), h. 152

${ }^{12}$ Sayyid Sabiq, Fiqh Sunnah, jilid XIV, (Beirut: Dar al-Fikry, t.th.), h. 148. Wakaf mempunyai padanan kata yang banyak dalam kajian hukum Islam, bahkan selain yang telah disebutkan di atas, wakaf juga memiliki sinonim yang lainnya yaitu: tahrim dan sabīl yang keduanya banyak ditemukan dalam kajian hadis. Siah Khasyi'ah, Wakaf dan Hibah Perspektif Ulama Fiqh dan Perkembangannya di Indonesia (Cet. ke-1; Bandung, Pustaka Setia, 2010), h. 16

${ }^{13}$ Pengertian wakaf di kalangan mazhab Syafi'i telah dikembangkan dengan beberapa pendapat; yaitu : Imam Nawawi mendefenisikan wakaf ialah menahan harta yang dapat diambil manfaatnya bukan untuk dirinya sementara benda itu tetap ada dan digunakan manfaatnya untuk kebaikan dan mendekatkan diri kepada Allah. Al-Syarbini mendefenisikan wakaf adalah menahan harta yang bisa diambil manfaatnya dengan menjaga keamanan benda tersebut dan memutuskan kepemilikan barang tersebut dari pemiliknya untuk hal-hal yang dibolehkan. Muhammad Abid Abdullah al-Kabīsī, Hukum Wakaf, alih bahasa Ahrul Sani dkk., (Cet. ke-1; Depok: IIMaN Press, 2004), h. 40
} 
untuk kebajikan bersama, sehingga wakif tidak boleh bertindak hukum terhadap harta tersebut. ${ }^{14}$

Wakaf adalah perbuatan hukum wakif untuk memisahkan dan/atau menyerahkan sebagian harta benda miliknya untuk dimanfaatkan selamanya atau untuk jangka waktu tertentu sesuai dengan kepentingannya guna keperluan ibadah dan/atau kesejahteraan umum menurut syari'ah (UU No. 41/2004 : Psl. 1). Kesimpulannya wakaf adalah "menahan asal dan mengalirkan hasilnya". Pokok harta yang diwakafkan tetap utuh dan hasil pengelolaannya yang dimanfaatkan bagi kepentingan publik.

\section{Jenis Wakaf yang Dikelola}

- Wakaf Tanah

Informasi yang diperoleh dari Sekretariat PB. Alkhairaat bahwa di seluruh tempat di mana ada madrasah, dapat ditemukan wakaf tanah. Luasnya bervariasi, mulai dari $\pm 90 \mathrm{~m}^{2}$ sampai dengan \pm 50 ha. Di Poso terdapat wakaf tanah milik Alkhairaat yang mempunyai nilai ekonomis tinggi. ${ }^{15}$ Di Kecamatan Kintom Kabupaten Banggai ada tanah wakaf yang luasnya mencapai puluhan hektar. ${ }^{16}$ Khusus di Kota Palu dan sekitarnya, juga ada wakaf tanah walaupun jumlahnya sangat kecil dibandingkan dengan luas lokasi wakaf di tingkat Propinsi. Luas lokasi wakaf Alkhairaat berada pada posisi $\pm 0.66 \%$ dari jumlah total luas lokasi wakaf di Sulteng. Luas lokasi Kota Palu berada pada posisi $\pm 48.4 \%$ dari jumlah total luas lokasi wakaf di Kota Palu; Kabupaten

${ }^{14}$ Abdul Aziz Dahlan (et. Al.), Ensiklopedi Hukum Islam (Cet. ke-1; Jakarta: Ichtiar Baru van Hoeve, 1996), h. 1905. Ibrāhim Mahmūd 'Abd al-Bāqī menyimpulkan bahwa pemaknaan wakaf dikalangan para ahli dapat dikelompokkan menjadi tiga, yakni: pandangan Imam Hanafi ra, pandangan Imam Malik, dan pandangan jumhur. Ibrāhīm Mahmūe 'Abd al-Bāqī, Daur alWaqf..., h. 26-27

${ }^{15}$ Ibrahim Ismail, wawancara via telepon, Palu; 12 September 2012.

${ }^{16}$ Rinaldi Samula, wawancara via telepon, Palu, 12 September 2012 
Donggala pada posisi $\pm 10.33 \%$; Kabupaten Parigi Moutong pada posisi $\pm 29.89 \%^{17}$

\section{- Wakaf Pohon Kelapa dan Sawah}

Kantor Pengurus Besar dan Yayasan Alkhairaat Belum memiliki data riil wakaf pohon kelapa secara keseluruhan; tetapi jumlah yang terdata diperkirakan \pm 600 pohon. Jumlah ini masih bertambah jika pendataannya dilakukan dengan baik. Misalnya di Kabupaten Touna ada lokasi perkebunan Alkhairaat, di dalamnya terdapat wakaf pohon kelapa; demikian juga di beberapa desa lainnya. ${ }^{18}$ Sementara wakaf sawah hanya ada satu lokasi; dan lokasi tersebut sudah termasuk satu di antara lokasi wakaf tanah yang telah dijelaskan sebelumnya. Oleh sebab itu, informasi lebih lanjut tentang keadaan dan perkembangan sawah ini tidak ditemukan.

\section{- Wakaf Saham dan Dana Abadi}

Jumlah sertifikat saham yang diterima dari sekretariat Pengurus Besar Alkhairaat hanya 7 lembar, selebihnya belum ada penjelasan karena tidak dibuat dalam bentuk daftar tabel atau daftar induk pemberi saham. Bagaimana pun besar kecilnya nilai saham yang ada, pada kenyataannya Alkhairaat telah menerima wakaf dalam bentuk saham. Adapun "dana abadi"19 mulai

\footnotetext{
${ }^{17}$ Data diperoleh dari dua sumber yakni data di Kantor BPN Kota Palu dan Kemenag Kota Palu.

${ }^{18}$ Amilin A. Bulungo, wawancara, Palu, 20 Oktober 2012

${ }^{19}$ Esensi wakaf adalah dijamin kelestarian pokoknya yang tidak boleh dijual, dihibahkan, dan diwariskan; dapat memberi manfaat bagi umat untuk kebaikan. Lihat: Abdullah Sa'ad Al-Hajiry, Taqyīm Kafā'ah Istismār Amwāl alAwqāf bi Daulah Kuwait (Kuwait: Idārah al-Dirāsah wa al-Allaqat al-Khārijiyah, 2006), h. 61. Keterangan lebih lanjut dapat ditemukan diberbagai kitab fiqh baik klasik maupun kontemporer. Uang adalah sesuatu yang memiliki fleksibilitas dan kemaslahatan besar yang tidak dimiliki benda lainnya. Lihat Konsideran Fatwa MUI tentang Wakaf Uang. Lihat juga: Khalid Mażkūr al-Mażkūr, Waqf alNuqūd wa al-Awrāq al-Māliyah dalam "Muntadiy Qaḍaya al-Waqf al-Fiqhiyyah al-S̄ānī Tahdiyāt Aṣriyyah wa Ijtihādāt Syar'iyah (Kuwait: Idārah al-Dirāsah wa al-Allaqat al-Kharijiyah, 2005), h. 71. Jika demikian, maka penyebutan "dana
} 
digalangkan oleh Alkhairaat pada tahun 2001. Dana ini salah satu upaya yang dilakukan oleh Yayasan dan dipandang sebagai format baru sistem keuangan dalam kerangka meningkatkan mutu pendidikan. Dalam Laporan yang disampaikan Ketua Yayasan tentang sumber dan jumlah penerimaannya disebutkan sejumlah uang dari donatur. Kegiatan penggalangan dana umat tersebut, mendahului keputusan MUI tentang Wakaf Uang yang dikeluarkan pada tanggal 11 Mei 2002. Bagi abna' Alkhairaat ketika uang itu diwakafkan, maka pengelolaannya sesuai dengan ketentuan yang berlaku di wakaf pada umumnya, sehingga ketika ada aspirasi yang lahir akan adanya "dana abadi bagi Alkhairaat", hal itu dianggap suatu perbuatan yang tidak bertentangan dengan syari'at Islam. ${ }^{20}$ Oleh sebab itu, mendonasikan uang sebagai wakaf yang dikembangkan oleh Alkhairaat telah membuka pintu bagi pengembangan investasi besar-besaran dalam perhimpunan Alkhairaat.

\section{Bentuk Lembaga Pengelola Wakaf}

Merujuk pada UU Nomor 41 Tahun 2004, pengelola wakaf dibagi menjadi tiga kelompok, yakni: perseorangan, organisasi dan badan hukum. Nazir perseorangan adalah nazir yang terdiri dari individu, atau kumpulan individu yang secara kolektif mengelola harta wakaf, yang biasanya tidak memiliki struktur kepengurusan yang jelas dan tidak memiliki kekuatan hukum ${ }^{21}$.

abadi" oleh Alkhairaat sesungguhnya adalah bagian dari pemaknaan wakaf uang atau wakaf tunai. Jika fatwa MUI dikeluarkan pada tahun 2002; maka Alkhairaat sebenarnya lebih dahulu membuat ketetapan tentang kebolehan Wakaf Uang.

${ }^{20}$ Muhammad Nur Aba, wawancara, Palu, 12 September 2012

${ }^{21}$ Nazir jenis ini banyak melahirkan masalah dalam pengelolaan wakaf. Alkhairaat termasuk organisasi yang menghadapi masalah dimaksud, misalnya: harta wakaf diambil alih kembali oleh ahli warisnya setelah wakifnya meninggal, ada juga yang dijual oleh ahli waris, (Husein, wawancara, Palu 15 Oktober 2012) perbuatan seperti ini bertentangan dengan makna wakaf. Memang banyak faktor penyebab penyalahgunaan wakaf, tetapi dengan nazir yang bersifat perseorangan dapat melahirkan keleluasaan dan sekehendak hati 
Pengelolaan wakaf di Alkhairaat melibatkan tiga jenis kelembagaan yang saling berhubungan; yakni Pengurus Besar, Yayasan dan Badan Otonom. Pengurus Besar berfungsi melaksanakan kebijakan dan strategi pengelolaan kekayaan perhimpunan. Yayasan berfungsi menghasilkan pendapatan organisasi khususnya keuangan dan harta benda, beserta implikasi yang timbul dari usaha dimaksud. Sedangkan badan otonom berfungsi membantu melaksanakan kebijakan Alkhairaat yang berkaitan dengan masyarakat tertentu. ${ }^{22}$ Nazir dipahami sebagai seseorang atau kelompok yang ditunjuk oleh atau mewakili Perhimpunan untuk menerima harta benda/kekayaan wakaf yang diberikan oleh seseorang atau lembaga kepada Alkhairaat. Nazir terdiri dari pengurus perhimpunan pada masing-masing tingkatan. Proses penentuan nazir berdasarkan keputusan rapat pengurus di masing-masing tingkatan. Sementara penerimaan wakaf dapat diterima langsung oleh perhimpunan atau nazir yang ditunjuk oleh perhimpunan Alkhairaat. ${ }^{23}$

Merujuk pada Undang-undang Wakaf, Pengurus Besar dan Yayasan memungkinkan untuk menjadi nazir; karena keduanya mengelola usaha di bidang pendidikan dan kebudayaan serta mengembangkan usaha sosial. Namun ketika persyaratan yang dimaksudkan dalam UU dan PP tentang wakaf itu adalah organisasi yang khusus mengelola wakaf, itu berarti organisasi dan badan hukum Alkhairaat yang dijelaskan di atas, belum dapat

menggunakan wakaf tanpa control. Suhrawardi K Lubis, dkk., Wakaf dan Pemberdayaan ..., h. 169

${ }^{22}$ Masyarakat tertentu dimaksud sesuai dengan jenis badan otonom, yaitu : Wanita Islam Alkhairaat berfungsi membantu melaksanakan kebijakan perhimpunan yang berhubungan langsung dengan komunitas wanita Alkhairaat, HPA berfungsi mengurus komunitas kepemudaan Alkhairaat, dan demikian yang lainnya (ART, psl 13).

${ }^{23}$ Peraturan Organisasi Pengurus Besar Alkhairaat Nomor 07 Tahun 2009 tentang Harta Benda/Kekayaan-kekayaan Milik Perhimpunan Allhairaat dan Organisasi di Lingkungan Alkhairaat, pasal 1 dan 3. 
dikatakan sebagai organisasi dan badan hukum yang berwenang menjadi nazir, melainkan sebagai organisasi sosial keagamaan biasa.

Dilihat dari aspek manajemen, terdapat kesimpangsiuran dalam hal hak mengatur dan mengurus wakaf. Nampak adanya dua peran organisasi dan badan hukum yang terpusat pada obyek yang sama. Pengurus Besar membuat laporan pengelolaan wakaf, demikian juga Yayasan. Padahal Pengurus Besar yang memiliki fungsi dan tanggung jawab lebih luas, secara struktural memberikan wewenang pengelolaan wakaf kepada yayasan (PO. No. 01/PO-PBA/2009, psl. 10; PO. No. 07/PO-PBA/2009, psl. 8). ${ }^{24}$

Sistem administrasi data wakaf Alkhairaat dapat diperoleh sebagian di Sekretariat Pengurus Besar, tetapi dalam laporan Ketua Yayasan pun menyebutkan masalah wakaf. Di satu sisim Peran PB sebagai nazir tergambar dengan Akte Ikrar Wakaf (AIW) yang dikeluarkan oleh KUA Kecamatan Palu Barat tentang penyerahan sebidang tanah di kompleks Alkhairaat Pusat, dimana

${ }^{24}$ Lihat: Peraturan Organisasi Pengurus Besar Alkhairaat Nomor 01 Tahun 2009 tentang Pembinaan Yayasan di Lingkungan Perhimpunan Alkhairaat, pasal 10; Lihat juga: Peraturan Organisasi PBA Nomor 07 Tahun 2009, pasal 8. Selanjutnya, sebagai bahan perbandingan, Yayasan Hasyim Asy'ari-misalnya-fungsi yayasan membawahi semua kegiatan pendidikan di pesantren Tebuireng; termasuk badan nazir wakafnya. Yayasan ini memiliki aset wakaf yang cukup besar jumlahnya. Pengelolaan wakaf dilakukan oleh Badan Nazir yang bertanggung jawab kepada Yayasan. Model ini berbeda dengan di Pondok Pesantren Modern Gontor yang juga mempunyai badan wakaf dan yayasan; tetapi badan wakafnya merupakan lembaga tertinggi di Gontor yang menjadi badan legislatifnya yang bertanggung jawab atas pelaksanaan dan perkembangan pendidikan dan pengajaran di Gontor. Di bawah badan wakafnya ada yayasan yang diberi nama Yayasan Pemeliharaan dan Perluasan Wakaf Pondok Modern yang bertugas mengelola aset dan mengembangkan harta wakaf. Yayasan ini ditunjuk oleh Badan Wakaf dengan konsentrasi pada upaya menggali dan menggalang serta mengembangkan dana dari dalam untuk keberlangsungan proses pendidikan dan pengajaran. Lihat: Nurul Iman, Wakaf dan Kemandirian Pendidikan Studi Pengelolaan Wakaf di Pondok Modern Darussalam Gontor, Disertasi; PPs IAIN Walisongo, 2012, h. 194-202 
nazir adalah Ketua Umum PB karena jabatannya. Di sisi lain, Direktur Swalayan Alkhairaat juga mengeluarkan Sertifikat Saham Wakaf yang diketahui oleh Pengurus Besar dan Ketua Utama Alkhairaat.

Berdasarkan Gambaran di atas, dapat dipahami bahwa bentuk pengelolaan wakaf Alkhairaat adalah "perseorangan, organisasi dan badan hukum." Seluruh bentuk pengelola ini diakui dalam peraturan perhimpunan Alkhairaat. Namun, ketika pembentukan lembaga kenaziran harus dilaporkan dan diregistrasikan kepada Badan Wakaf Indonesia melalui KUA setempat. Dalam hal ini belum ada data pendukung atas keabsahan nazir organisasi dan badan hukum dimaksud. Walaupun dalam kajian hukum Islam tidak ada ketentuan yang menyatakan bahwa nazir harus diregistrasi, tetapi UU wakaf memberi peluang untuk perbaikan sistem pembinaan pengelolaan nazir di berbagai lembaga sosial kemasyarakatan.

\section{Manajemen Wakaf Alkhairaat}

Produktivitas menjadi harapan setiap orang, tetapi produktivitas tidak akan dicapai jika aspek manajerialnya tidak dikelola dengan baik. Oleh karena itu, proses manajemen pengelolaan adalah alat yang digunakan untuk mencapai sasaran tersebut. $^{25}$

Pengelolaan wakaf Alkhairaat dapat dilihat pada beberapa sudut pandang:

\section{Aspek tujuan}

Wakaf yang dikelola oleh perhimpunan Alkhairaat, digolongkan kepada wakaf khairī, yakni wakaf yang sejak semula ditujukan untuk kepentingan umum dan tidak ditujukan kepada orang-orang tertentu. ${ }^{26}$ Hasil pengelolaan seluruh jenis wakaf,

${ }^{25}$ J. Winardi, Manajemen Perilaku Organisasi (Cet. ke-1; Jakarta: Prenada Kencana, 2004), h. 22

${ }^{26}$ Lihat: Ibrāhīm Maḥmūd 'Abd al-Bāqī, Daur al-Waqf..., h. 41-42 
semata-mata diperuntukkan bagi kepentingan pembangunan: madrasah, pondok pesantren, masjid, dan sebagainya. Pemanfaatannya untuk pendidikan, sementara pendidikan itu merupakan bagian dari kepentingan publik, olehnya itu wakaf tersebut telah memberi maslahat publik. Walaupun maslahat dimaksud belum menyentuh pada kesejahteraan, keadilan, kesehatan, atau usaha.

\section{Aspek batasan waktu}

Wakaf dari aspek batasan waktu terdiri atas : wakaf abadi dan wakaf sementara. Wakaf abadi adalah wakaf yang jika barangnya berbentuk benda yang bersifat abadi atau tahan lama, misalnya tanah, bagunan, atau benda bergerak lainnya yang memiliki sifat abadi. Adapun wakaf sementara ialah barang yang diwakafkan berupa barang yang mudah rusak, atau barang yang karena wakifnya memberikan batasan waktu pada saat mewakafkan hartanya itu. ${ }^{27}$ Status harta wakaf Alkhairaat adalah jenis harta yang tahan lama dan tidak mudah rusak. Hasyim Assaqaf, menjelaskan bahwa wakaf yang diterima Alkhairaat adalah benda yang mempunyai sifat tahan lama, sebab bendanya berupa tanah, pohon kelapa, sawah, dan perkebunan. Ini semua jenis harta yang memang tidak dapat diprediksi rusaknya atau habis zatnya. ${ }^{28}$

\section{Aspek produktivitas}

Wakaf dari sistem pemanfaatannya dibagi dua; yakni wakaf langsung dan wakaf produktif. Wakaf langsung adalah wakaf yang dilakukan untuk memberi pelayanan langsung kepada yang berhak, seperti masjid, sekolah, rumah sakit, dan sebagainya.

\footnotetext{
${ }^{27}$ Munz̧ir Qahaf, Al-Waqf al-Islāmī Tațawwuruhu, Idāratuhu, Tanmiyyatuhu, diterjemahkan oleh Muhyiddin Mas Rida dengan judul Manajemen Wakaf Produktif (Cet. ke-3; Jakarta: Khalifa, 2000), h. 162; Jaih Mubarak, Wakaf Produktif (Cet. ke-1; Bandung: Simbiosa Rekatama Media, 2008), h. 43-44

${ }^{28}$ Hasyim Assaqaf, wawancara, Palu, 11 Oktober 2012
} 
Wakaf produktif adalah wakaf yang pokoknya digunakan untuk kegiatan produktif atau dikelola sedemikian rupa agar mendatangkan hasil dan hasilnya itu yang akan diberikan kepada yang berhak sesuai tujuan wakaf. ${ }^{29}$

Alkhairaat menerapkan kedua-duanya. Wakaf langsung misalnya: wakaf tanah diperuntukkan pada pembangunan madrasah, masjid, dan pondok pesantren; sebagaimana dijelaskan oleh Abdurrahman H. Halim. ${ }^{30}$ Wakaf produktif juga dikembangkan, misalnya: Gedung Serba Guna, Swalayan, dan penambahan pohon kelapa sebanyak 2016; kemudian perkebunan coklat seluas 50 ha; demikian juga pengembangan lokasi wakaf seluas 30 ha digunakan untuk sawah semuanya mengarah kepada "usaha ekonomi". ${ }^{11}$

\section{Aspek manajemen}

Pengelolaan wakaf Alkhairaat Palu tampak kurang efisien dan efektif, sebab proses pengelolaannya ditangani oleh Pengurus Besar dan Yayasan. Aturan organisasi mendelegasikan kepada Yayasan sebagai pengelola wakaf; tetapi secara administratif juga dilakukan oleh Pengurus Besar. Pola ini melahirkan sikap saling lepas tanggung jawab. Belum ditemukan penerapan sistem manajemen sebagaimana yang biasanya digunakan dalam berbagai model pengelolaan harta kekayaan dan usaha ekonomi.

Perencanaan (planning), pengelolaan wakaf mencakup: upaya meningkatkan pelaksanaan inventarisasi wakaf; meningkatkan Akta Ikrar Wakaf dan Sertifikasi Tanah Wakaf; menyusun sistem pengelolaan wakaf; melakukan pembinaan; dan menyelesaikan wakaf yang bermasalah. Program ini merupakan perencanaan dalam pengelolaan wakaf Alkhairaat, tetapi data

\footnotetext{
${ }^{29}$ Munzir Qahaf, Ibid.

${ }^{30}$ Abdurrahman H. Halim, wawancara, Palu, 12 September 2012

${ }^{31}$ Huzaimah Yanggo, Sayyid Idrus bin Salim al-Jufrie Pendiri Alkhairaat dan Kontribusinya dalam Pembinaan Umat (Cet. ke-1; Jakarta: Gaung Persada, 2013), h. 257
} 
yang ada menunjukkan belum terealisasi sesuai dengan yang direncanakan itu. Program ini juga belum menyentuh sistem penggalangan, meningkatkan jumlah harta wakaf, meningkatkan manfaat hasil wakaf melalui kegiatan produktif, dan sebagainya.

Pengorganisasian, fungsi ini menuntut adanya lembaga kenaziran. Pembentukan lembaga kenaziran merupakan bagian dari perancangan dan pengembangan suatu organisasi atau kelompok kerja yang dapat membawa ke arah tujuan yang diharapkan. Belum terbentuknya lembaga kenaziran, memberi pengaruh pada proses penyusunan personalia untuk kepentingan kelembagaan. Penyusunan personalia dimaksud adalah melakukan penarikan, pelatihan, pengembangan serta penempatan dan pemberian orientasi para karyawan dalam lingkungan kerja agar dapat menguntungkan dan melahirkan produktivitas.

Demikian juga pada aspek pengarahan, karena belum adanya lembaga kenaziran maka sistem pengarahan belum dapat diterapkan. Aspek pengarahan adalah upaya pimpinan organisasi atau yang berwenang untuk memberikan pengarahan kepada personalia organisasi tentang tugas dan rencana masing-masing yang seharusnya dikerjakan menuju pada tujuan yang telah ditentukan. Terakhir fungsi pengawasan yakni penemuan dan penerapan cara serta peralatan untuk menjamin bahwa rencana telah dilaksanakan sesuai dengan yang telah ditetapkan. Pengawasan itu upaya yang dilakukan seseorang diberbagai bidang berkaitan dengan administrasi dalam bentuk pengarahan kebijakan jalannya organisasi.

Selain fungsi manajemen sebagaimana telah di jelaskan di atas, juga ada beberapa jenis manajemen yang sangat strategis tetapi belum diterapkan oleh Alkhairaat, yakni: manajemen sumber daya manusia dan manajemen investasi. Jika ini diterapkan maka akan semakin memperkuat sistem kelembagaan wakaf Alkhairaat. 
- Manajemen Sumber Daya Manusia

Sumber daya manusia dipandang sangat fundamental, sebab semua pengelolaan organisasi akan bermuara pada manusianya. Manusia tidak mungkin diperlakukan sama dengan alat produksi lainnya, melainkan harus diperlakukan sesuai dengan harkat dan martabatnya. ${ }^{32}$ Pengembangan sumber daya manusia mencakup: manusia sebagai administrator, manajer, pelaksana tugas.

Upaya pengembangan SDM dilakukan melalui perencanaan, yakni langkah yang ditempuh oleh manajemen guna lebih menjamin bahwa dalam organisasi telah tersedia tenaga kerja untuk menduduki berbagai kedudukan dalam rangka pencapaian tujuan dan program yang telah ditetapkan. Tujuan dapat berfungsi sebagai alat dan motivasi terhadap karyawan, dan akhirnya menjadi alat evaluasi dan pengendalian yang efektif Oleh sebab itu, ada lima pilar mendasar perencanaan tenaga kerja, yaitu: a) menentukan kebutuhan tenaga kerja; b) perkiraan kebutuhan tenaga kerja; c) perkiraan penerimaan tenaga kerja dari dalam dan luar organisasi; d) adanya instrumen dasar penilaian tenaga kerja; dan e) mempersiapkan kemungkinan kebutuhan tenaga kerja.

Selain perencenaan juga harus ada pengembangan SDM yang bertujuan meningkatkan kemampuan melaksanakan tugas baru di masa mendatang sekaligus menjadi bagian dari program investasi SDM jangka panjang. Manfaatnya yaitu: lahirnya peningkatan produktifitas kerja organisasi, terwujudnya hubungan yang serasi antara atasan dan bawahan, terjadinya pengambilan keputusan yang lebih cepat dan tepat, meningkatnya semangat kerja seluruh tenaga kerja, mendorong

\footnotetext{
${ }^{32}$ Manusia memiliki harkat dan martabat yang terdepan dari semua makhluk yang mempunyai kedudukan muhtaram. Bahkan kedudukan tersebut dalam QS. Al-Isra' ayat 70 disebut "al-karāmah al-insāniyyah". Lihat Ali Yafie, Menggagas Fiqh Sosial dari Soal Lingkungan Hidup, Asuransi hingga Ukhuwah (Cet. ke-2; Bandung: Mizan, 1996), h. 166
} 
sikap keterbukaan manajemen; memperlancar jalannya komunikasi yang efektif. Oleh karena itu, mengembangkan tenaga kerja dalam sebuah organisasi adalah sesuatu yang pokok, menjadi tiang dasar dari manajemen yang baik. Pengembangan tenaga kerja akan melahirkan kecakapan dalam berkerja. Kecakapan tenaga kerja merupakan kekayaan organisasi yang paling besar. Usaha meningkatkan asset tenaga kerja akan menjadi investasi (Terry, 2010:224) ${ }^{33}$.

- Menerapkan Manajemen Investasi

Investasi berarti penundaan konsumsi saat ini untuk konsumsi di masa mendatang. Investasi berarti menempatkan modal atau suatu aset yang diharapkan akan memberikan hasil atau akan meningkatkan nilainya di masa mendatang. Investasi berarti diawali dengan mengorbankan potensi konsumsi saat ini untuk mendapatkan peluang yang lebih baik di masa datang. Ini memberikan penegasan bahwa investasi merupakan bentuk usaha yang dilakukan dengan menyertakan modal dalam usaha bersama, lalu dengan modal tersebut diharapkan dapat memberi keuntungan bagi kedua pihak, sesuai dengan hasil yang diperolehnya. Jenis modal investasi dapat bermacam-macam yang dalam kajian wakaf bisa harta benda bergerak dan harta benda tidak bergerak.

Pembiayaan dapat saja berasal dari perorangan atau lembaga, dewasa ini orang selalu melirik ke dunia perbankan. Perbankan telah menyediakan berbagai jenis pembiayaan, yang meliputi: membiayai suatu proyek; membiayai nasabah untuk memperoleh harta tetap; membiayai nasabah untuk memperoleh modal kerja. Veithzal berpandangan bahwa realisasi bentuk

${ }^{33}$ Yuniarsih menambahkan bahwa Pengembangan tenaga kerja dan pegawai merupakan aktivitas memelihara dan meningkatkan kompetensi tenaga kerja guna mencapai efektivitas organisasi. Sasaran pengembangan tenaga kerja dapat diwujudkan melalui pengembangan karir, pendidikan dan pelatihan. Lihat: Tjutju Yuniarsih, Manajemen Sumber Daya Manusia (Cet. ke2; Bandung: Alfabeta, 2009), h. 133 
pembiayaan bank terhadap kegiatan investasi dapat berupa : a) investasi berdasarkan hukum mudāarabah. ${ }^{34}$ Sistem ini bank sebagai pemilik modal menyediakan seluruh uang tunai untuk membiayai proyek dan nasabah mengurus dan mengusahakannya; nisbah bagi hasil antara kedua belah pihak disetujui dan dipastikan dalam perjanjian; ${ }^{35}$ b) investasi berdasarkan sistem musyarakah atau biasa disebut joint-venture; yakni keikutsertaan dua orang atau lebih pada suatu usaha tertentu dengan sejumlah modal yang ditetapkan berdasarkan perjanjian; c) investasi berdasarkan hukum sewa. Jenis ini dimaksudkan adalah transaksi pemindahan hak guna atas barang/jasa dalam batasan waktu tertentu melalui pembayaran upah sewa tanpa diikuti dengan pemindahan hak pemilikan atas barang.

\footnotetext{
${ }^{34}$ Veithzal, Islamic Financial..., h. 425-426. Status hukum mudārabah telah disepakati oleh para fuqaha dibolehkan dengan alasan memiliki tujuan untuk saling membantu antara pemilik modal dengan seorang yang ahli dalam memutar modal. Kebolehan tersebut didasarkan pada firman Allah swt pada surah al-Muzammil (73): 20. Lihat: Abdul Aziz Dahlan (et. Al.), Ensiklopedi..., h. 1196. Hasil yang diperoleh dari system kerjasama ini (laba yang diperoleh) menjadi milik bersama, yang dibagi berdasarkan kesepakatan. Lihat: Taqiyuddin, Kifāyat al-Akhyār, jilid I, terj. Syarifuddin Anwar (Cet. ke-2; Surabaya: Bina Iman, 1995), h. 685; Wahbah al-Zuhaili, al-Fiqh al-Islāmī wa Adillatuh, juz 2, (Beirut: Dār al-Fikry, t.th.), h. 189

${ }^{35}$ Syafi'i Antonio memberikan gambaran jika sistem mudharabah itu dikembangkan bersama bank, maka ada dua posisi bank yang boleh dilakukan, yakni: sebagai mitra antara penabung maupun pengusaha yang meminjam dana. Bersama penabung, bank bertindak sebagai mudharib atau pengelola; sedangkan penabung bertindak sebagai shahib al-mal atau penyandang dana. Antara kedua pihak mengadakan akad mudharabah yang akan menyatakan keuntungan masing-masing pihak. Di sisi lain, bersama pengusaha atau peminjam dana; bank akan bertindak sebagai shahib al-mâl (penyandang dana, baik yang berasal dari tabungan/deposito/giro maupun dana bank sendiri berupa modal pemegang saham). Posisi pengusaha berfungsi sebagai mudharib atau pengelola karena melakukan usaha dengan memutar dan mengelola dana bank. Muhammad Syafii Antonio, Bank Syari'ah dari Teori ke Praktek (Cet. ke12; Jakarta: Gema Insani Press, 2010), h. 137
} 


\section{Faktor Pendukung dan Penghambat Pengelolaan Wakaf}

\section{Alkhairaat}

\section{Faktor pendukung manajerial pengelolaan wakaf}

- Alkhairaat telah terbentuk dalam wadah perhimpunan besar

Perguruan ini dari segi keroganisasian telah tersusun dengan sempurna, pengurusnya di mulai dari tingkat pusat hingga ranting. Adanya struktur organisasi yang jangkauannya begitu luas, sangat strategis untuk membuat keputusan institusi tentang standarisasi pengelolaan organisasi yang baik. Organisasi ini dapat menerapkan manajemen struktur yang selalu mempertimbangkan kedudukan, fungsi dan tugas setiap personalia dalam strukturnya. Manajemen ini melihat organisasi dalam bentuk yang berbeda-beda, tetapi merupakan sistem yang komponennya secara keseluruhan saling berhubungan. Kemapanan struktur organisasi yang melangsungkan prosesnya secara tersistem akan dapat menyelesaikan tujuan secara efektif. ${ }^{36}$

- Lembaga Alkhairaat telah berakar pada kehidupan masyarakat

Sejak didirikan pada tahun 1930 M., lembaga ini telah bersentuhan langsung dengan masyarakat melalui madrasah yang dibangunnya, dan berhasil menamatkan siswa-siswi yang secara terus-menerus sejak tahun 1933 sampai sekarang. Ini menjadi bukti bahwa madrasah ini telah memberi pengaruh besar bagi kehidupan masyarakat. ${ }^{37}$ Alumni madrasah Alkhairaat telah banyak yang menduduki jabatan strategis di pemerintahan dan di berbagai lembaga lainnya. Berkembangnya madrasah sampai ke pelosok di Kawasan Timur Indonesia menjadi bukti bahwa lembaga tersebut tidak dapat dipisahkan lagi dengan kehidupan masyarakat. Banyaknya siswa dan santri yang masuk berlajar di

\footnotetext{
${ }^{36}$ Onong Uchjana Effendy, Ilmu Komunikasi Teori dan Praktek (Cet. ke22; Bandung: Remaja Rosdakarya, 2009), h. 114

${ }^{37}$ Huzaimah Yanggo, Sayyid Idrus..., h. 134
} 
lembaga ini juga merupakan bagian dari bukti perhatian masyarakat.

- Alkhairaat memiliki potensi harta wakaf

Memang masih sulit diketahui dengan pasti jumlah harta wakaf keseluruhan karena belum optimalnya pendataan, pemetaan, dan pengelolaannya; namun diakui bahwa hampir di setiap wilayah dan tempat di Sulawesi Tengah, terdapat harta wakaf Alkhairaat. Bahkan akhir-akhir ini ada penambahan wakaf yaitu: pohon kelapa sebanyak 2016, perkebunan coklat seluas 50 ha, dan sebagainya. ${ }^{38}$

- Alkhairaat memiliki sumber daya manusia

SDM yang dimiliki oleh perhimpunan ini dibagi menjadi 4 (empat) kelompok, yakni: 1) pengurus organisasi; 2) siswa/santri, mahasiswa, guru/dosen; 3) alumni; 4) simpatisan. Selain empat kelompok itu, ditetapkan pula jenis keanggotaan perhimpunan yakni: 1) anggota biasa ialah WNI yang beragama Islam dan setuju dengan Anggaran Dasar dan Anggaran Rumah Tangga Perhimpunan; 2) anggota luar biasa ialah WNI yang dinilai berjasa kepada Perhimpunan; dan 3) anggota kehormatan ialah mereka yang dinilai mempunyai karya besar di bidang kemanusiaan dan ilmu pengetahuan (Psl. 4).

- Potensi pengembangan lahan produktif masih terbuka luas

Perguruan Alkhairaat dilihat dari aspek topografis berada pada daerah dan kawasan yang lahan dan hutannya masih sangat luas. Kawasan Timur Indonesia merupakan kawasan yang kepadatan penduduknya jauh lebih kecil dibandingkan pulau Sumatera dan Jawa. Luas daratan pulau Sulawesi $\pm 173.583 \mathrm{~km}^{2}$, dan luas daratan Sulawesi Tengah $\pm 63.305 \mathrm{~km}^{2}$ (36.47\%) dari total luas daratan Sulawesi atau mencapai $6.330 .466 \mathrm{ha}^{39}$. Luas wilayah

\footnotetext{
${ }^{38}$ Ibid., h. 257

${ }^{39}$ Data Statistik Wilayah Propinsi Sulawesi Tengah tahun 2010.
} 
dengan jumlah penduduk yang hanya $\pm 3,4$ juta jiwa, menunjukkan besarnya potensi lahan produktif yang dapat dijadikan wakaf.

- Memiliki Sarana Prasarana Pendukung

Alkhairaat telah memiliki berbagai sarana pendukung bagi tercapainya tujuan pendidikan. Madrasah/sekolah di seluruh daerah dan tempat telah memiliki gedung yang digunakan untuk proses belajar mengajar, demikian juga sekretariat pengurusnya. Walaupun masih terdapat kekurangan yang perlu diupayakan ke depan seiring dengan kompleksnya persoalan pendidikan. Ketersediaan sarana prasarana telah memberi peran penting bagi jalannya roda organisasi.

\section{Hambatan manajerial pengelolaan wakaf Alkhairaat}

- Alkhairaat belum memiliki sistem informasi yang baik.

Era global dewasa ini, tidak ada lagi sekat dalam akses informasi, sehingga semua lapisan masyarakat mempunyai kesempatan yang sama untuk mengembangkan diri dalam segala aspek kehidupannya. ${ }^{40}$ Komputer, televisi, radio, telepon, dan sebagainya; telah dimiliki Alkhairaat, namun media yang ada belum dapat digunakan secara maksimal; sebab belum ada panduan yang dapat dijadikan sarana menghubungkan seluruh kegiatan keorganisasian (termasuk wakaf). Ketua Yayasan menyatakan bahwa Alkhairaat masih mengalami banyak kendala dalam pengelolaan wakaf disebabkan oleh karena belum memiliki sistem informasi yang baik.

- Pengelola wakaf yang tidak berbentuk badan hukum

Pengelola wakaf berdasarkan ketentuan harus berada di wilayah atau tempat dimana harta wakaf itu berada. ${ }^{41}$ Bagi

\footnotetext{
${ }^{40}$ Udin Syaefudin Sa'ud, Inovasi Pendidikan (Cet. ke-1; Bandung: Alfabeta, 2010), h. 185-186

${ }^{41}$ Lihat: Taufiq Hamami, Perwakafan Tanah dalam Politik Hukum Agraria Nasional (Cet. ke-1; Jakarta: Tatanusa, 2003), h. 101. Lihat juga : PP. Nomor 42 Tahun 2006 tentang Pelaksanaan UU Nomor 41 Tahun 2004 tentang Wakaf; pasal 4-12; PP.
} 
organisasi atau badan hukum harus memiliki perwakilan dimana harta wakaf itu berada. Perhimpunan Alkhairaat yang sejak awal telah mempunyai harta wakaf, sesungguhnya belum memiliki lembaga kenazirannya. Peraturan organisasi Alkhairaat memang tegas menjelaskan perannya dalam menerima, mengelola dan mengembangkan wakaf, tapi berdasarkan ketentuan perundangundangan seharusnya dibentuk lembaga khusus perwakafan. Inilah nantinya yang didaftarkan untuk menjadi nazir organisasi atau badan hukum.

- Pengelola wakaf belum memenuhi standarisasi nazir.

Profesionalitas telah tergambar dari makna wakaf, yakni: wakaf perbuatan mulia dan membutuhkan keikhlasan ${ }^{42}$, menuntut ketelitian dalam mengeluarkan harta milik agar harta yang diwakafkan memberi manfaat dan nilai ${ }^{43}$, dijamin kelanggengannya, sasarannya jelas, ada yang mengelolanya, dan diadministrasikan. Pengelola wakaf disebut nazir yang oleh ulama disepakati sebagai wakil dari orang yang mewakafkan hartanya. ${ }^{44}$

Nomor 28 Tahun 1977 tentang Perwakafan Tanah Milik, pasal 6; PP. Nomor 42 Tahun 2006 tentang Pelaksanaan UU Nomor 41 Tahun 2004 tentang Wakaf; pasal 412). PP. Nomor 28 Tahun 1977 tentang Perwakafan Tanah Milik, pasal 6.

${ }^{42}$ Lihat: Q.S. al-Bayyinah (97): 5, ayat ini mengajarkan agar dalam melakukan sesuatu harus diikuti dengan keikhlasan.

${ }^{43}$ Lihat: Q.S. al-Baqarah (2): 177, untuk memdapatkan kebaikan di sisi Allah swt, bukanlah semata-mata menghadapkan wajah kita ke arah timur dan barat; tetapi juga mengeluarkan harta yang dimiliki dan harta itu dicintainya.

${ }^{44}$ Nazir sebagai wakil, mewakili dua kelompok; kelompok pemilik dan kelompok mustahik. Selama wakif masih hidup, maka tindakannya harus sesuai dengan petunjuk wakif. Wakif berhak memecat atau memberhentikan dengan sebab atau tanpa sebab. Nazir sebagai wakil dari mustahik, karena dia bekerja untuk kepentingan mereka sesuai dengan hakikat wakaf membagikan manfaat darinya. Orang yang mendapatkan hak atas manfaat harta wakaf adalah mereka yang dimaksudkan sebagai fakir miskin dan lain sebagainya. Pengangkatan nazir, untuk menjaga dan membagikan harta manfaat wakaf itu kepada yang berhak. Nazir adalah wakil mereka dan mengatasnamakan kepentingan mereka. Lihat Muhammad Abid Abdullah al-Kabisi, Hukum Wakaf, alih bahasa Ahrul Sani, dkk., (Cet. ke-1; Jakarta: Dompet Dhuafa Republika \& IIMaN, 2004), h. 518-522 
Pengelola wakaf di Alkhairaat sangat terbatas, kurang memiliki kemampuan $^{45}$, dan belum ada sistem yang baku. Abd. Rahman Halim (wawancara, 2012) mengungkapkan bahwa seharusnya seluruh wakaf terdata di Sekretariat PB; namun hal ini belum bisa terlaksana karena yang mengurus langsung seluruh urusan yang berhubungan dengan wakaf dibebankan pada seorang saja. ${ }^{46}$

Oleh sebab itu, untuk mengelola wakaf nazir harus memiliki banyak kemampuan; termasuk kemampuan teknis, social, dan konseptual. ${ }^{47}$ Nazir dituntut memiliki kemampuan secara menyeluruh terhadap pengelolaan wakaf. Kemampuan itulah yang dalam manajemen dinyatakan sebagai penggerak keterlibatan karyawan, focus kepada pelanggan (wakif dan mustahik), penentuan acuan (metode, perencanaan, dsb), dan perbaikan terus menerus. ${ }^{48}$

- Tidak ada dana operasionalisasi pengelolaan wakaf

Sebagai lembaga yang bergerak dibidang pendidikan masalah pembiayaan menjadi kendala umum. ${ }^{49}$ Wakaf sebagai bagian dari harta lembaga mengalami dampak atas masalah pembiayaan. Kondisi ini diakui oleh Wakil Sekjen Saiful Tompoh, bahwa memang ada beberapa program yang telah dicanangkan oleh bidang pembangunan/wakaf seperti: inventarisasi, tabulasi, sertifikasi; ini semua belum dapat terlaksana. ${ }^{50}$ Pihak Kemenag RI

${ }^{45}$ Kemampuan dimaksud mencakup : a) memahami tentang falsafah wakaf; b) memahami tentang institusi wakaf; c) memahami tentang administrasi; d) memahami tentang pembinaan dan pengawasan.

${ }^{46}$ Abdurrahman H. Halim, wawancara, Palu, 12 September 2012

${ }^{47}$ Lihat: Paul Hersey, dkk, Manajemen Perilaku Organisasi Pendayagunaan Sumber Daya Manusia, edisi IV ( Jakarta : Erlangga, 2004), h. 5. 2006), h. 77

${ }^{48}$ Lihat: Richard L. Daft, Manajement, edisi 6 (Jakarta: Salemba Empat,

${ }^{49}$ Ada pemikiran yang berkembang bahwa alternatif melepaskan diri dari kekurangan pembiayaan dalam pengelolaan pendidikan adalah lembaga tersebut diotonomisasikan. Lihat: H. Haidar Daulay Putra, Pemberdayaan Pendidikan Islam di Indonesia (Cet. ke-1; Jakarta: Rineka Cipta, 2004), h. 70.

${ }^{50}$ Saiful Tompoh, wawancara, Palu, 20 Oktober 2012 
pun mengakui untuk menjamin kelanggengan harta wakaf agar terus menerus memberikan pelayanan prima sesuai dengan tujuannya diperlukan dana pemeliharaan. Bagaimana bisa tanah wakaf melahirkan produktifitas jika tidak ada pengairan, pupuk, bibit, dan sebagainya; semua ini membutuhkan anggaran. ${ }^{51}$

- Sistem kepemimpinan yang bersifat sentralistik

Sistem pengelolaan wakaf Alkhairaat masih kuat didominasi oleh pemahaman bahwa keabsahan dan keberkatan wakaf itu hanya bisa terjadi jika yang menerima wakaf adalah pimpinan tertinggi Alkhairaat. Memang semua kalangan di Alkhairaat masih mengakui akan peran pimpinan tertinggi (memiliki kharismatik); tetapi berhubung wakaf merupakan harta umat, sistem manajemen pengelolaan pun harus dapat dibuktikan kembali kepada umat. Oleh sebab itu, mengalihkan kepercayaan masyarakat terhadap pengaruh kepemimpinan menjadi bertumpu pada organisasinya adalah sesuatu yang terus diupayakan. Strateginya dengan membentuk lembaga pengelola wakaf yang otonom, kemudian melalui lembaga inilah yang berperan aktif menepis dan meluruskan pemahaman warga dan masyarakat untuk berwakaf. Walaupun demikian, peran sentral kepemimpinan yang ada tidak mungkin dihilangkan dalam struktur keorganisasian; sebab hal itu bagian dari ciri lembaga pendidikan yang berbasis keagamaan.

\section{Solusi Manajerial Pengelolaan Wakaf Alkhairaat}

Upaya mencapai tujuan pengelolaan wakaf dan jawaban atas masalah yang menjadi penyebab belum optimalnya wakaf Alkhairaat, maka pola manajemennya berbentuk manajemen

\footnotetext{
${ }^{51}$ Departemen Agama RI, Pedoman Pengelolaan dan Pengembangan Wakaf(Jakarta : Direktorat Pemberdayaan Wakaf Direktorat Bimas Islam, 2006), h. 112-113.
} 
perusahaan ${ }^{52}$ yang tetap berbasis pada kepentingan mauqūf 'alaih (tujuan wakaf) dan komunitas setempat. ${ }^{53}$ Ini dapat diciptakan melalui skema: a) membentuk dewan pengawas yang terdiri dari ahli waris, nazir, masyarakat setempat, LSM; b) menciptakan kriteria dan efisiensi manajerial yang dapat diterapkan untuk semua jenis aset wakaf dan tujuannya. Syafi'i Antonio berpendapat seperti dikutip Muhyar Fanani bahwa ada tiga karakter pengelolaan wakaf professional, yaitu: pola manajemen harus dalam bingkai proyek yang terintegrasi; asas kesejahteraan nazir; asas transparansi dan akuntabilitas. ${ }^{54}$ Secara sederhana system manajemen pengelolaan wakaf dapat mengikuti pola Kemenag RI sebagai acuan, yaitu:

\section{- Aspek kelembagaan}

Jika selama ini wakaf Alkhairaat hanya dikelola oleh satu orang saja; maka kondisi ini perlu diperbaiki. Caranya membentuk lembaga otonom pengelola wakaf agar memberi peluang berjalannya seluruh potensi kelembagaan. Adapun format kelembagaan wakaf tergantung pada Alkhairaat. Pembentukan lembaga kenaziran akan membuka peluang mekanisme kerja lembaga lebih terstruktur dan terorganisir.

- Aspek operasional

Mengelola wakaf memerlukan standar operasional yaitu batasan atau garis kebijakan dalam pengelolaan agar menghasilkan sesuatu yang lebih bermanfaat bagi kepentingan public. Standar dimaksud merupakan rangkaian program kerja yang dapat menghasilkan sebuah produk, yang mendasarkan

\footnotetext{
${ }^{52}$ Pola ini dikemukakan oleh Munzir Qahaf seperti dikutip dalam Muhyar Fanani, Berwakaf Tak Harus Kaya, Dinamika Pengelolaan Wakaf Uang di Indonesia (Cet. ke-1; Semarang: Walisongo Press, 2010), h. 211.

${ }^{53}$ Uraian manajemen wakaf yang ideal juga menurut Sherafat Ali Hashmi yang dikutip oleh Tuty (2006:139) menyerupai manajemen perusahaan yang berarti peranan kuncinya adalah pada eksistensi nazir bersama tim kerja yang solid.

${ }^{54}$ Muhyar Fanani, Berwakaf Tak Harus..., h. 212.
} 
pada lima fungsi utama, yakni: proses, kapasitas, sediaan, tenaga kerja, dan mutu ${ }^{55}$.

- Aspek kehumasan

Pengelola wakaf harus melakukan langkah memperkuat image bahwa harta benda wakaf yang telah diamanatkan kepada lembaga dapat dikembangkan dengan sebaik-baiknya dan hasilnya dimanfaatkan bagi kepentingan umat; memberi keyakinan kepada wakif kalau wakafnya akan dikelola secara professional dan termasuk mampu menarik orang lain untuk berwakaf; mendakwakan terhadap peran dan potensi ganda yang dimiliki oleh wakaf yaitu mendapatkan pahala yang tak hentihentinya dan telah memberikan dukungan social kemanusiaan terutama bagi masyarakat kurang mampu.

- Aspek sistem keuangan

Keuangan merupakan sesuatu yang dianggap paling sensitif dalam langkah gerak manusia. Mengatur keuangan biasanya menggunakan teori "akuntansi dan auditing." Akuntansi mengarahkan pada pertanggungjawaban yang dibentuk dalam format laporan. Laporan diorientasikan pada neraca penerimaan dan pengeluaran, yang mengindikasikan keuntungan atau kerugian. Aplikasi akuntansi ini dapat dilakukan oleh organisasi

\footnotetext{
${ }^{55}$ Memperhatikan pencapaian mutu merupakan bagian dari proses pengelolaan wakaf menunjukkan akan pentingnya majamen mutu atau biasa dikenal dengan “Total Quality Manajemen".TQM memiliki arti "sistem manajemen yang mengangkat kualitas sebagai strategi usaha dan berorientasi pada kepuasaan pelanggan dengan melibatkan seluruh anggota organisasi. Lihat: Fandy Tjiptono dan Anastasia Diana, Total Quality Management, edisi revisi (Cet. ke-3; Yogyakarta: Andi, 2003), h. 4 dan 14-18. Pengelolaan kualitas semua komponen (stakeholder) yang berkepentingan dengan visi, misi organisasi lihat: Kuat Ismanto, Manajemen Syari'ah Implementasi TQM dalam Lembaga Keuangan Syari'ah (Cet. ke-1; Yogyakarta: Pustaka Pelajar, 2009), h. 69. Prinsipnya adalah kepuasan pelanggan, respek terhadap setiap orang, manajemen berdasarkan fakta, dan perbaikan berkesinambungan, obsesi terhadap kualitas, komitmen jangka panjang, kerja sama tim (team work), kesatuan tujuan, dan adanya keterlibatan dan pemberdayaan karyawan.
} 
yang bermotifkan profit oriented dan organisasi yang bersifat nirlaba (non profit). Sementara auditing adalah pihak pengelola membuat laporan secara terbuka sesuai dengan tugas dan amanah yang diberikan kepadanya kepada pihak yang memberi amanah.

- Aspek Spiritualitas dan Moralitas

Pesan yang tersirat dalam wakaf menuntut kepada pengelola: agar mempunyai pengetahuan agama; memiliki integritas kepribadian (sikap terpuji dan amanah); mempunyai sikap lebih memperhatikan kepentingan publik sesuai tujuan perwakafan. Aspek spiritualitas dan moral ini akan mengantarkan pengelola sadar pertanggungjawaban amanah itu dihadapan: Allah $^{56}$, kelembagaan, hukum, dan sosial.

\section{PENUTUP}

Bentuk pengelolaan wakaf Alkhairaat adalah perseorangan, organisasi dan badan hukum sebagaimana diakui dalam peraturan perhimpunan. Namun, ketika pembentukan lembaga kenaziran harus dilaporkan dan diregistrasikan kepada Badan Wakaf Indonesia melalui KUA setempat, maka belum ada data pendukung atas keabsahan nazir organisasi dan badan hukum dimaksud; seperti diamanatkan UU. Pengelolaan wakaf masih berada dalam bingkai program Pengurus Besar dan Yayasannya; serta masih terintegrasi dengan bidang lainnya dalam perhimpunan.

Sistem manajemen dalam pengelolaan wakaf Alkhairaat dilihat dalam bentuk program telah mengindikasikan adanya penerapan fungsi manajemen; tetapi dilihat dari realitas pendataan, pengembangan, dan sebagainya hanyalah teori

56 Allah swt. menyatakan dalam Q.S. al-Ankabut (29):13 “dan sesungguhnya mereka akan memikul beban-beban mereka dan beberapa beban beserta pikulan-pikulan mereka, dan mereka akan ditanyai perihal dusta yang mereka ada-adakan." 
semata. Antara data di sekretariat PB dengan lapangan berbeda. Hal ini semakin jauh jika dihubungkan dengan penerapan manajemen lainnya, misalnya : manajemen SDM dan manajemen Investasi. Wakaf yang berada di hampir seluruh wilayah kerja Alkhairaat dari aspek manajemen harus diakui masih lemah.

Manajemen dapat diterapkan di pengelolaan wakaf Alkhairaat karena: Alkhairaat telah terbentuk dalam perhimpunan besar, telah berakar dalam kehidupan masyarakat, memiliki potensi harta wakaf, memiliki sumber daya manusia, potensi pengembangan lahan produktif masih terbuka luas, dan memiliki sarana prasarana. Tetapi, perhimpunan ini juga masih menghadapi kendala menerapkan sistem manajemen di sisi yang lain, yakni : belum memiliki sistem informasi yang baik, pengelola wakaf yang tidak berbentuk badan hukum, pengelola wakaf belum memenuhi standarisasi nazir, tidak memiliki dana operasionalisasi wakaf, dan sistem kepemimpinan yang bersifat sentralistik.

Berdasarkan teori dan fakta data di lapangan menunjukkan bahwa wakaf Alkhairaat belum dikelola secara maksimal dengan menggunakan manajemen. Kondisi ini disebabkan oleh lembaga wakafnya belum terbentuk secara mandiri yang juga memberi implikasi pada penerapan sistem manajemen. Pengelolaannya bersifat tradisional tak berdaya; kurang memperhatikan : aspek kelembagaannya, standarisasi kemampuan pengelolanya, manfaat dan pengembangan harta wakaf. Akibatnya wakaf tidak memiliki : daya dorong bagi pengembangan ekonomi perhimpunan, daya tarik kepercayaan public, daya penentu system pengelolaan perekonomian perhimpunan, serta daya saing atau kompetisi kelembagaan baik internal maupun eksternal.

\section{DAFTAR PUSTAKA}

Ali, Zainuddin. Metode Penelitian Hukum, Cet. ke-2 ; Jakarta: Sinar Grafika, 2010. 
Antonio, Muhammad Syafii, Bank Syari'ah dari Teori ke Praktek, Cet. ke-12; Jakarta: Gema Insani Press, 2010.

Bāqī, Ibrāhīm Maḥmūd 'Abd al-Bāqī, Daur al-Waqf fị Tanmiyat alMujtama' al-Madanī, Namūzuj al-Amānah al-'Āmmah li alAwqāf bi Daulah al-Kuwait, Disertasi, Kuwait, 2006.

Daft, Richard L., Manajement (terj.), edisi. 6, Jakarta: Salemba Empat, 2006.

Dahlan, Abdul Aziz (et. Al.), Ensiklopedi Hukum Islam, Cet. ke-1; Jakarta : Ichtiar Baru van Hoeve, 1996.

Daulay, H. Haidar Putra, Pemberdayaan Pendidikan Islam di Indonesia, Cet. ke-1; Jakarta : Rineka Cipta, 2009.

Effendy, Onong Uchjana, Ilmu Komunikasi Teori dan Praktek, Cet. ke-22; Bandung : Remaja Rosdakarya, 2009.

Fadel, Muhammad, Sambutan Ketua Yayasan Alkhairaat pada Muktamar Besar VIII Alkhairaat tahun 2002, Palu, 2002.

Fanani, Muhyar, Pengelolaan Wakaf Tunai Studi Perbandingan atas Lembaga Tabung Wakaf Indonesia, Pos Keadilan Peduli Umat, dan Baitul Mal Mu'amalat, Laporan Penelitian Individual, Semarang; IAIN Walisongo, 2009.

Fuad, Muhammad, Membangunkan Raksasa Tidur Problematika Pengelolaan dan Pendayagunaan Wakaf di Indonesia, Cet. ke-1; Jakarta: Piramedia, 2008.

Hajiry, Abdullah Sa'ad al-. Taqyimu Kafa'atu Istismar Amwal alAwqaf bi Daulati Kuwait, Kuwait, Idarah al-Dirasat wa alAllaqat al-Kharijiyah, 2006.

Hamami, H. Taufiq, Perwakafan Tanah dalam Politik Hukum Agraria Nasional, Cet. ke-1; Jakarta: Tatanusa, 2003.

Hersey, Paul, dkk., Manajemen Perilaku Organisasi Pendayagunaan Sumber Daya Manusia, edisi IV, Jakarta: Erlangga, 2004. 
Iman, Nurul, Wakaf dan Kemandirian Pendidikan (Studi Pengelolaan Wakaf di Pondok Modern Darussalam Gontor Ponorogo), Disertasi PPs IAIN Walisongo, 2012.

Ismanto, Kuat, Manajemen Syari'ah Implementasi TQM dalam Lembaga Keuangan Syari'ah, Cet. ke-1; Yogyakarta: Pustaka Pelajar, 2009.

Kabīsī, Muhammad Abid Abdullah al-, Hukum Wakaf, alih bahasa Ahrul Sani dkk, Cet. ke-1; Depok: IIMaN Press, 2004.

Khasyi'ah, Siah, Wakaf dan Hibah Perspektif Ulama Fiqh dan Perkembangannya di Indonesia, Cet. ke-1; Bandung: Pustaka Setia, 2010.

Lubis, Suhrawardi K. dkk., Wakaf dan Pemberdayaan Umat, Cet. ke-1; Jakarta : Sinar Grafika, 2010.

Mażkūr, Khalid Mażkūr al-, Waqf al-Nuqūd wa al-Awrāq alMāliyah dalam "Muntadiy Qậāya al-Waqf al-Fiqhiyyah alŚānī Tahdiyāt Așriyyah wa Ijtihādāt Syar'iyah, Kuwait: Idārah al-Dirāsah wa al-Allaqat al-Kharijiyah, 2005

Mubarak, Jaih, Wakaf Produktif, Cet. ke-1; Bandung: Simbiosa Rekatama Media, 2008.

Mudhafir, Ali, Kamus Teori dan Aliran dalam Filsafat dan Teologiy, Cet. ke-1; Yogyakarta: UGM Press, 1996.

Muhammad, Fadel, Sambutan Ketua Yayasan Alkhairaat pada Muktamar Besar VIII, Palu, 2002.

Najib, Tuti A. (ed.), Wakaf, Tuhan dan Agenda Kemanusiaan Studi tentang Wakaf dalam Perspektif Keadilan Sosial di Indonesia, cet. 1; Jakarta : CSRC UIN Syarif, 2006.

Nasution, Edwin, ed., "Peran Badan Wakaf Indonesia (BWI) dalam Pengembangan Wakaf di Indonesia" dalam Jurnal al-Awqaf, vol. 1 (nomor 01), 2008. 
Onong Uchjana Effendy, Ilmu Komunikasi Teori dan Praktek, Cet. ke-22; Bandung: Remaja Rosdakarya.

Peraturan Organisasi Pengurus Besar Alkhairaat Nomor 07 Tahun 2009 tentang Harta Benda/Kekayaan-kekayaan Milik Perhimpunan Allhairaat dan Organisasi di Lingkungan Alkhairaat

Peraturan Pemerintah, Nomor 28 tahun 1977, tentang Perwakafan Tanah Milik. LN RI Tahun 1977 Nomor 38

Peraturan Pemerintah, Nomor 42 tahun 2006, tentang Pelaksanaan Undang-undang Nomor 41 tahun 2004. LN RI tahun 2006 Nomor 105

Qahaf, Munẓir, Al-Waqf al-Islāmī Tațawwuruhu, Idāratuhu, Tanmiyyatuhu, diterjemahkan oleh Muhyiddin Mas Rida dengan judul Manajemen Wakaf Produktif , Cet. ke-3; Jakarta: Khalifa, 2000.

Rivai, H. Veithzal, Islamic Financial Management, Cet. ke-1; Bogor: Ghalia Indonesia, 2010.

Sa'ud, Udin Syaefudin, Inovasi Pendidikan, Cet. ke-1; Bandung: Alfabeta, 2010.

Sabiq, Sayyid, Fiqh Sunnah, jilid XIV, Beirut: Dar al-Fikry, t.th.

Salim, Abd. Muin, Fiqh Siyasah, Konsepsi Kekuasaan Politik dalam Alqur'an, Cet. ke-2; Jakarta: Raja Grafindo Persada, 1995.

Suhadi, H. Imam. Wakaf untuk Kesejahteraan Umat, Cet. ke-1; Yogyakarta : Dana Bhakti Prima Yasa, 2002.

Taqiyuddin, Kifāyat al-Akhyār, jilid I, terj. Syarifuddin Anwar, Cet. ke-2; Surabaya: Bina Iman, 1995

Tim Penyusun, 1994, Kamus Besar Bahasa Indonesia, edisi II cet. 3; Jakarta : Balai Pustaka.

Tjiptono, Fandy dan Anastasia Diana, Total Quality Management, edisi revisi, Cet. ke-3; Yogyakarta: Andi, 2003 
Winardi, J., Manajemen Perilaku Organisasi, Cet. ke-1; Jakarta: Prenada Kencana, 2004.

Yafie, H. Ali, Menggagas Fiqh Sosial dari Soal Lingkungan Hidup, Asuransi hingga Ukhuwah, Cet. ke-2; Bandung: Mizan, 1996.

Yanggo, H. Huzaimah. Sayyid Idrus bin Salim al-Jufrie Pendiri Alkhairaat dan Kontribusinya dalam Pembinaan Umat, cet. 1; Jakarta : Gaung Persada, 2013.

Yuniarsih, Tjutju, Manajemen Sumber Daya Manusia, Cet. ke-2; Bandung: Alfabeta, 2009.

Zuhaili, Wahbah al-, al-Fiqh al-Islāmī wa Adillatuh, juz 2, Beirut: Dār al-Fikry, t.th. 